\title{
The application of single cell gel electrophor esis or comet assay to human monitoring studies
}

Mahara Valverde, M.I.B.B., ${ }^{(1)}$ Patricia 0 strosky-Wegman, Ph.D., ${ }^{(1)}$ Emilio Rojas, Ph.D., ${ }^{(1)}$ Teresa Fortoul, M. en N., ${ }^{(2)}$ Fernando Meneses, M.C., ${ }^{(3)}$ Matiana Ramírez, M.C., ${ }^{(3)}$ Fernando Díaz-Barriga, Ph.D., ${ }^{(4)}$ Mariano Cebrian, Ph.D. ${ }^{(5)}$

\section{Valverde M, Ostrosky-Wegman P, Rojas E, Fortoul T, Meneses F, Ramírez M, Díaz-Barriga F, Cebrian M. The application of single cell gel electrophoresis or comet assay to human monitoring studies. Salud Publica Mex 1999; 41 suppl 2:S109-S113.}

\begin{abstract}
A bstract
Objective. In the search of new human genotoxic biomarkers, the single cell gel electrophoresis assay has been proposed as a sensible alternative. Material and methods. This technique detects principally single strand breaks as well as alkali-labile and repair-retarded sites. Results. Herein we present our experience using the single cell gel electrophoresis assay in human population studies, both occupationally and environmentally exposed. Conclusions. We discuss the assay feasibility as a genotoxic biomarker.
\end{abstract}

Keywords: biological markers; single cell gel electrophoresis assay
Valverde M, Ostrosky-Wegman P, Rojas E, Fortoul T, Meneses F, Ramírez M, Díaz-Barriga F, Cebrian M.

Aplicacion de la electroforesis

unicelular o ensayo cometa en estudios

de monitoreo humano.

Salud Publica Mex 1999; 41 supl 2:S109-S113.

\section{Resumen}

Objetivo. En la búsqueda de nuevos marcadores genotóxicos aplicables a estudios de poblaciones humanas expuestos a xeno bióticos, la utilización del ensayo de electroforesis en una sola célula se ha propuesto como un método sensible y una buena alternativa. Material y métodos. Esta técnica detecta rompimientos en el ADN de cadena sencilla, así como sitios álcali lábiles y sitios retardados de reparación. Resultados. En este trabajo, presentamos nuestra experiencia utilizando este ensayo en poblaciones humanas expuestas ocupacionalmente 0 ambientalmente a diferentes xenobióticos. Conclusiones. Se discute la posible utilidad de este ensayo como un biomarcador de efecto genotóxico.

Palabras clave: marcadores biológicos; ensayo de electroforesis en gel de células individuales
$\mathrm{H}$ uman monitoring involves the use of biological or molecular markers as indicators to signal events in individuals exposed to environmental chemicals. Therefore, human monitoring may lead to identification of potential hazardous exposures before adverse health effects appear and also establish exposure limits for minimizing the likelihood of significant health risks. ${ }^{1}$

Three specific types of biological markers are identified. The first is a biological marker of exposure, that

(1) Instituto de Investigaciones Biomédicas, Universidad N acional Autónoma de México (UN AM).

(2) Facultad de Medicina, UN AM.

(3) Instituto $\mathrm{N}$ acional de Salud Pública, México.

(4) Facultad de Medicina, Universidad Autónoma de San Luis Potosí, México.

(5) Centro de Investigación y Estudios Avanzados, Instituto Politécnico N acional, México.

Recibed on: June 3,1998 • Accepted on: A pril 7,1999

Reprint requests to: Dr. Emilio Rojas del Castillo. Instituto de Investigaciones Biomédicas, Universidad Nacional Autónoma de México.A.P. 70228, Ciudad Universitaria, 04510 México, D.F., México. E-mail:emilior@ servidor.unam.mx 
may be the xenobiotic chemical itself, its metabolites or the product of an interaction between the chemical and its target biomolecule. ${ }^{2}$ These indicators can be measured as the concentration of the material in urine, blood, hair, nails, any other tissue or the chemical bounds to macromolecules such as DNA and proteins. ${ }^{3}$ The second is a marker of susceptibility, whether inherited or induced, which indicates that the individual is particularly sensitive to the effect of a xenobiotic or to the effects of a group of such compounds. The third type is a marker of effect, which may be an endogenous component, a measure of the functional capacity, or some other indicator of the organs, system or body condition that might be affected by the exposure. Effect markers are generally pre-clinical indicators of abnormalities and the most frequently used are sister chromatid exchanges, ${ }^{4}$ chromosomal aberrations $^{5,6}$ and micronuclei. ${ }^{7}$ More recently, the use of the single cell gel electrophoresis assay or comet assay (SCGE) has been proposed as a useful biomarker for early effects. ${ }^{8-11}$

The relevance of the SCGE lies in its requirement of a reduced number of cell samples, its ability to evaluate DNA damage in non-proliferating cells ${ }^{12}$ and the fact that non-invasive procedures can be done to obtain a sufficient number of cells from different tissues. In contrast to cytogenetic biomonitoring studies which are mainly done with lymphocytes, the SCGE assay can be used with any cell population, which constitutes an advantage for these kind of studies. The SCGE assay has been used in about 20 human monitoring studies, ${ }^{13}$ mainly using human lymphocytes from exposed individuals; the results obtained were both positive and negative, and revealed considerable intra-individual variation, possibly reflecting the sensitivity of lymphocytes to physiological status. ${ }^{14}$ Taking advantage of the SCGE characteristics other cells had been used in monitoring studies, for example, Calderon et al ${ }^{15}$ obtained cells from nasal epithelial biopsies and also we were able to adapt the SCGE to cells obtained from the mouth's epithelium. ${ }^{16}$

Our work has focused in the evaluation of environmental problems in Mexico, mainly the exposure to air pollutants (ozone and gasoline), contaminated water (arsenic and fluoride), and pesticides.

\section{Material and methods}

Sampling. For the monitoring of arsenic (As) and fluor (F) in drinking water, gasoline fumes and pesticides (DDT, DDE), venous blood samples were collected and immediately sent to the laboratory to start the isolation of lymphocytes. Urine samples were collected, stored in plastic bottles at $4{ }^{\circ} \mathrm{C}$ and protected from light until the analysis was performed. In a previous step, all plastic bottles were soaked in $10 \%$ nitric acid, rinsed with bidistilled water and dried. In the case of environmental pollution $\left(\mathrm{O}_{3}\right)$, we draw $10 \mathrm{ml}$ of whole blood (leukocytes cells) by finger puncture, which was put in a heparinized eppendorf and then processed. Nasal epithelium cells were obtained with a disposable plastic curette through direct visual inspection. Using gentle pressure, the probe was drawn along the inferior surface of the nasal cavity several times and retracted backwards. The nasal epithelium sample obtained was immediately immersed in $1 \mathrm{ml}$ of cold RPMI-1640 medium. Finally, epithelial cells were obtained by scrapping the side walls of the mouth with a wooden stick and the samples were added to $1 \mathrm{ml}$ of cold RPMI-1640 medium. For this study all samples were collected at the same time and rapidly processed. Determination of As or F in urine, DDT, DDE and benzene in blood. Urine samples were digested according to the procedure recommended by Cox. ${ }^{17} A s$ and $F$ determinations were made with a Perkin-Elmer 3100 atomic absorption spectrophotometer equipped with a flow injection atomic spectroscopy system (FIAS-200). All measurements were made using a deuterium background corrector. Freeze-dried urine standard reference material for toxic metals (SRM 2670) was analyzed for total As or F and results obtained had $93-107 \%$ of the accuracy of the stated values and $9 \%$ of precision. Creatinine in urine was measured according to the method put forth by Boosnes and Tawssky. ${ }^{18}$

Lymphocyte isolation. The isolation method was described elsewhere. ${ }^{6}$ In brief, mononuclear cells were separated by Ficoll-Hypaque centrifugation, cryopreserved at $-70^{\circ} \mathrm{C}$ in RPMI- 1640 medium with $10 \%$ of autologous plasma and $7.5 \%$ dimethyl sulfoxide, at a cellular density of $10^{6}$ cells $/ \mathrm{ml}$.

Single cell gel electrophoresis (SCGE) assay. This assay was performed as described by Singh et al. ${ }^{19}$ with minor modifications. Briefly, after alkaline lysis $(2.5 \mathrm{M} \mathrm{NaCl}$, $100 \mathrm{mM}$ EDTA, $10 \mathrm{mM}$ Tris $\mathrm{pH} 10), 10 \%$ of DMSO and $1 \%$ of triton $\mathrm{X}-100$ at $4^{\circ} \mathrm{C}$ for $1 \mathrm{~h}$, slides were placed on a horizontal electrophoresis unit. The DNA was allowed to unwind for 20 minutes in electrophoresis running buffer solution $(300 \mathrm{mM} \mathrm{NaOH}$, and $1 \mathrm{mM}$ $\mathrm{Na}_{2}$ EDTA, $\mathrm{pH}$ 13). Electrophoresis was conducted for 20 minutes at $25 \mathrm{~V}$ and $300 \mathrm{~mA}$. All technical steps were conducted using very dim indirect light. After electrophoresis, the slides were gently removed and alkaline $\mathrm{pH}$ neutralized with $0.4 \mathrm{M}$ Tris, $\mathrm{pH7.5)}$. Ethidium bromide ( $75 \mu \mathrm{l}$ of a $20 \mu \mathrm{g} / \mathrm{ml}$ solution) was added to each slide and a coverglass was placed on the gel, DNA migration was analyzed on a Nikon Optiphot-2 micro- 
scope with fluorescence equipment (filter G-2A), and measured with a scaled ocular. For the evaluation of DNA migration (total image length), 50 cells were scored for each individual. Cloudy cells (cells with an extreme damage) were evaluated as a percentage cells in 200 cells scored for each concentration. This kind of cells were not included on the DNA migration values. Viability was evaluated immediately after isolation of lymphocytes by the incorporation of trypan blue. Statistical analyses performed include the use of Student $t$ tests, two-way ANOVA, and Mann Whitney U tests.

\section{Results and discussion}

In Mexico City the concentration of ozone overpasses the air quality standard very requently. The wind blows from north to south, sweeping the ozone precursors in the same direction, while suspended particles and hydrocarbons remain in the north and the central areas of the city. As a consequence of this uneven distribution of pollutants, the inhabitants of Mexico City have varying exposures to air pollutants. Lymphocytes, oral and nasal cells sampled from people who reside in the southern and the northern parts of the city were evaluated, and our main finding was an increased DNA single strand breaks in nasal epithelial cells and lymphocytes from individuals living in the southern regions of the city; in contrast, no differences were observed in oral epithelial cells between both groups, possibly due to antioxidative enzymes present in saliva (Figure 1). ${ }^{20}$

The volatile organic compounds are another important group of environmental pollutants. The most important one is benzene, because of the impact that chronic exposure to this compound has on health. Due extensive use of benzene in gasoline, the heavy traffic and the emission of gasoline fumes, high levels of benzene in air have been claimed in Mexico City. Due to this fact, we joined efforts with a group of scientists from the National Institute of Public Health and measured benzene exposure using personal monitors, its circulating blood levels and ran SCGEs in leukocytes from three groups of workers: gas station attendants, street-vendors and office employees. We found evidence of DNA damage (SSB) in the leukocytes from the gas station workers (high exposure), and a lesser effect in the two other groups (street workers= mid exposure category; and office workers= low exposure; see Figure 2). Our study is in agreement with the data generated by Andreoli et al., ${ }^{20}$ who found an increased frequency of DNA damage among individuals working in a gas station, and the observed benzene values were almost the same in both populations ( 0.031 and
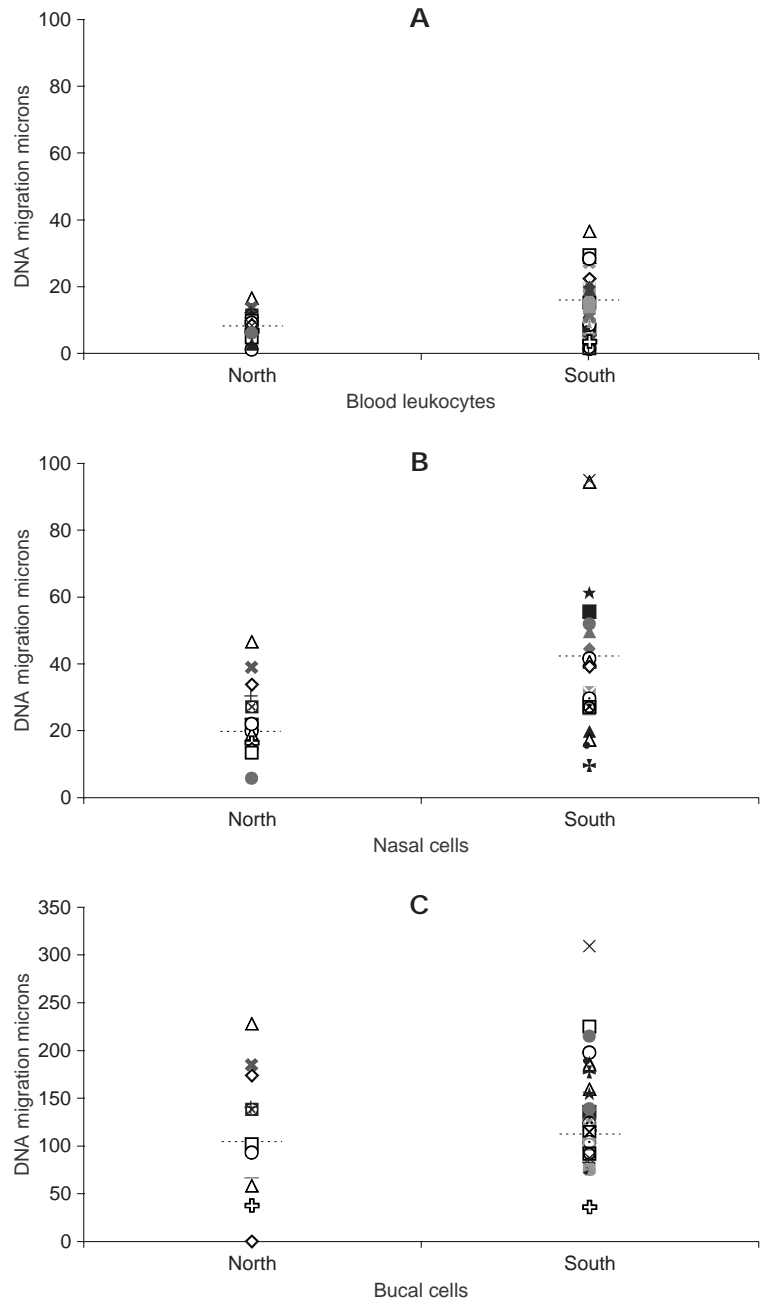

FIGURE 1. DNA MIGRATION IN INDIVIDUALS WHO LIVE IN the Northern AND southern parts OF MeXico City. A: Blood leukocytes, B: Nasal epithelial Cells. C: BuCCAL EPITHELIAL CELLS. $\mathbf{N}=\mathbf{4 8}$ INDIVIDUALS, STATISTICALLY SIGNIFICANCE P $<0.05$ MANN-WHITNEY TEST

$\left.0.036 \mu \mathrm{g} / \mathrm{m}^{3}\right)$. Nevertheless, there was no correlation between the benzene levels and the DNA damage at the individual level; this situation could be due to the fact that gasoline is a mix of different compounds and some of them are antagonist of benzene.

Arsenic (As) and fluoride had been found in very high concentrations in water from several states of Mexico. Arsenic has been a target problem studied by our group, and several in vivo and in vitro studies had been carried out to understand its carcinogenic mechanism..$^{22-25}$ In a group of individuals drinking water with an average of $0.410 \mathrm{mg} / 1$ of arsenic during several years, we found that subjects who have skin le- 


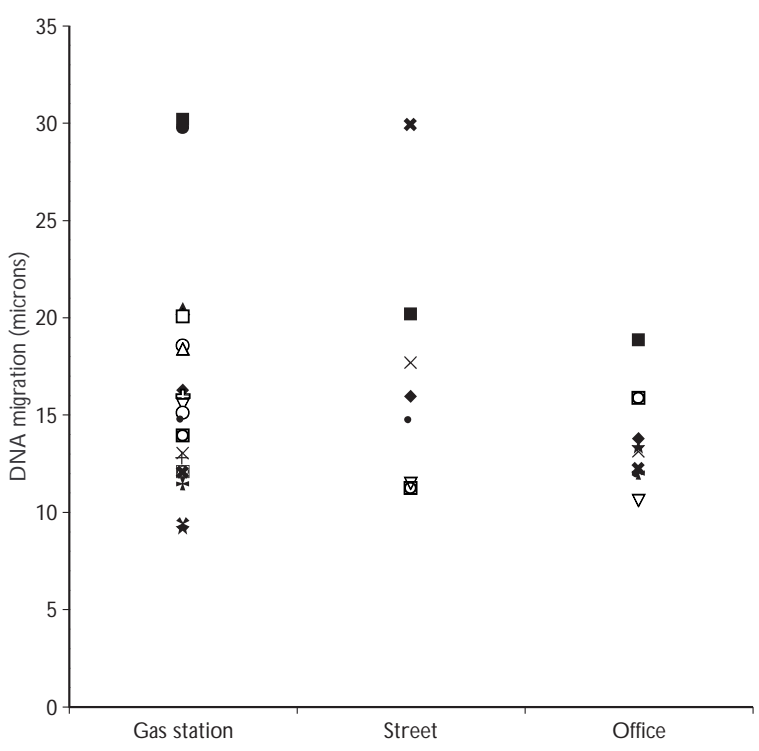

Figure 2. DNA MigRATION IN INDIVIDUALS EXPOSED TO DifFERENT benzene CONCENTRATION. A: GAS STATION attendants, B: Public throughfare workers and C: Office Workers. $\mathbf{N}=\mathbf{3 1}$ Individuals

sions also have an increased DNA migration (Figure 3). Although no correlation was observed with As urinary levels, it is interesting to point out that females with higher As urinary levels showed a higher possibility for DNA damage. This was not the case with exposure to fluoride, in which case an increased DNA damage was observed in highly exposed individuals, but no correlation was found with the concentration of fluoride in urine; it should be mentioned, however, that the latter was a pilot study that included only a small number of individuals (Figure 4).

It is hard to believe that 30 years after the publication of Raquel Carson's book The Silent Spring, ${ }^{26}$ which talks about the destructive potential of an indiscriminate use of pesticides, more than 10,000 cases of pesticide intoxication are still reported every year in our country. Several pesticides are massively used, including those as DDT that are banned in developed countries.

Since recent studies suggest that DDT could be an endocrine disruptor and one of the causes of breast cancer, we evaluated DNA damage in leukocytes obtained from females suffering from breast cancer, and compared the results with those obtained from a group of females affected by benign breast disease $(\mathrm{N}=96$ and 48 , respectively), in addition, DDT and DDE levels were measured in blood. No differences were observed be-

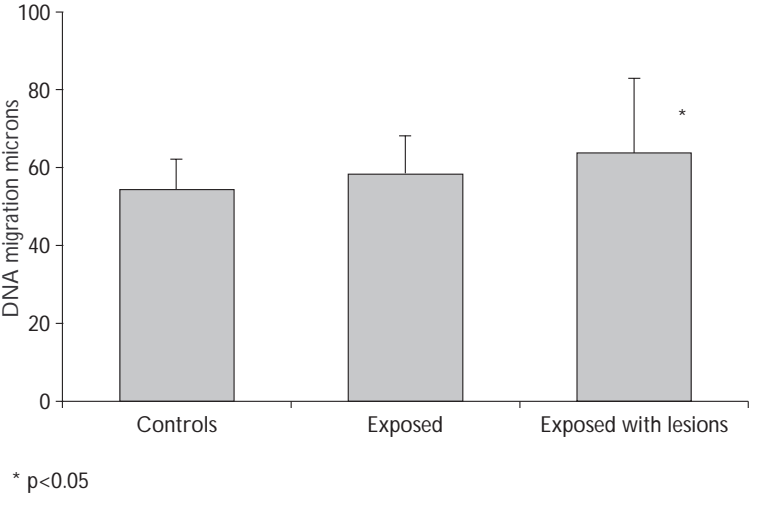

FigURE 3. DNA MigRATION IN LYMPHOCYTES FROM HUMANS EXPOSED TO DIFFERENT CONCENTRATIONS OF ARSENIC IN THEIR DRINKING WATER. A: CONTROLS, B: EXPOSED WITH SKIN LESIONS AND C: EXPOSED WITH SKIN LESIONS. $\mathrm{N}=56$ INDIVIDUALS. STATISTICALLY SIGNIFICANCE $\mathrm{P}<0.05$ TWO WAY ANOVA ANALYSYS

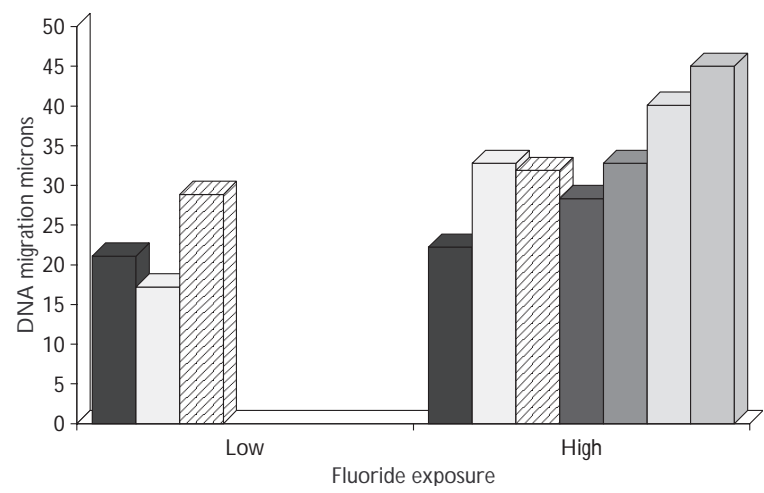

FIGURE 4. DNA MIGRATION IN LEUKOCYYTES FROM PERSONS EXPOSED TO FLUORIDE IN THEIR DRINKING WATER. EACH BAR REPRESENTS AN INDIVIDUAL. $\mathbf{N}=\mathbf{1 0}$. StatistICALLY SIGNIFICANCE P<0.05 MANN-WHITNEY TEST

tween both groups (see Table I). SCGE has shown to be sensitive in detecting DNA damage among individuals exposed to atmospheric pollution, gas station workers, people exposed to natural contaminants (As, F), but not among subjects exposed to DDT. It should be mentioned that the DDT levels found in blood were low, and the exposure took place years ago, hence, it and may be that leukocytes are not the appropriate cells to look for this kind of effects, since DDT is mainly accumulated in fat. 
Table 1

LeVELS OF DDT, DDE AND DNA MIGRATION IN WOMEN WITH BREAST CANCER AND BENIGN BREAST DISEASE

\begin{tabular}{lccc} 
& $\begin{array}{c}\mathrm{DDT} \\
\mu \mathrm{g} / \mathrm{ml}\end{array}$ & $\begin{array}{c}\mathrm{DDE} \\
\mu \mathrm{g} / \mathrm{ml}\end{array}$ & $\begin{array}{c}\text { DN A migration } \\
\mu \mathrm{m} \pm \mathrm{E} . \mathrm{S} .\end{array}$ \\
& & & \\
Breast cancer & $511 \pm 58.09$ & $404 \pm 54.19$ & $17.40 \pm 2.09$ \\
\hline Benign breast disease & $420 \pm 34.67$ & $318 \pm 30.65$ & $19.58 \pm 1.84$
\end{tabular}

The technique in our hands seems to be sensitive enough to detect DNA damage, but it is not specific. It is important to mention that (during recent years) the use of lesion-specific endonucleases (principally for oxidative damage) has increased the specificity of DNA damage detection, however, the use of these endonucleases for human monitoring purposes is not well established. It is also important to underline that almost all the groups herein studied were exposed to a variety of compounds, and any of those could be responsible for inducing the observed breakages.

Some questions must be answered before this method be considered as a useful effect biomarker: a) which are the appropriate sampling times and types of cells to perform the analyses?; b) do the results obtained in the SCGE assay correlate with other biomarkers of effect as sister chromatid exchanges (SCE), miconuclei (MN) or chromosomal aberrations (CA)?; and c) what is the persistence and the biological meaning of the damage observed with the SCGE?

\section{Acknowledgments}

We appreciate the support of Dr. Lizbeth López who did the epidemiological study of DDT effects and provided us with the blood samples, and also the technical help of M. C. López, M. Sordo, I. López and I. Sánchez.

\section{References}

1. Albertini RJ, Robison SH. Human population monitoring. In: Li AP, Heflich RH, eds. Genetic Toxicology. Boca Ratón:C RC Press, 1991;375:420. 2. Committe on Biological Markers of the $\mathrm{N}$ ational Research C ouncil. Biol Markeers in Environ Health Res 1987;74:3-9.

3. Grandjean P, Brown SS, Reavey P, Young DS. Biomarkers of chemical exposure: State of Art. C lin C hem 1994;40(7):1360-1362.

4. Tucker JD, A uletta A, C imino MC, D earfield KL,Jacobson-Kram D, Tice RR et al. Sister chromatid exchange: Second report of the Gene-Tox Program. Mutat Res 1993;297:101-180.
5. Anwar W A. Monitoring of human population at risk by different cytogenetic end points. Environ Health Perspect 1994;102 suppl 4:131-134. 6.0 strosky-W egman P, Gonsebatt ME. Environmental toxicants in developing countries. Environ Health Perspect 1996;104 (suppl 3):599- 602.

7. N orppa H, Luomahaara S, Heikanen H, Roth S, Sorsa M, Renzi L et al. Micronucleus assay in lymphocytes as a tool to biomonitor human exposure to aneuploidogens and clastogens. Environ H ealth Perspect 1993;101 suppl 3:139-143.

8. Tice RR. The single cell gel/comet assay. In: Phillips $D H$, Venitt $S$, eds. Environmental mutagenesis. 0 xford,U.K.: Bios Scientific Publishers LTD, 1995.

9. Singh N P, McC oy MT, Tice RR, Schneider EL. A simple technique for quantification of low levels of DNA damage in individual cells. Exp Cell Res 1988;175:184-191.

10. McKelvey-Martin VJ, G reen MHL, Schmezer P, Pool-Zobel BL, D e Meo MP, Collins A.The single cell gel electrophoresis (comet assay):An European review. Mutat Res 1993;288: 47-63.

11. Fairbairn DW, 0 live PL, 0 'N eill KL. The comet assay: An comprehensive review. Mutat Res 1995;339:37-59.

12. Hartmann A, Speit G. Comparative investigations of the genotoxic effects of metals in the single cell gel (SCG) assay and the sister chromatid exchange (SCE) test. Env Mol Mutagen 1994;23:299-305.

13. Comet Workshop. Croydon, UK May 8-10, 1997.

14. Ross GM, MCMillan TJ,W ilcox P, Collins AR. The single cell microgel electrophoresis assay (comet assay): Technical aspects and applications, Reports on the 5th LH Gray Trust Workshop, Institute of Cancer Research,1994. Mutat Res 1995;337:57-60.

15. C alderón-G arcidueñas L, 0 snaya-Brizuela N , Ramírez-Martínez L,ViIlareal-Calderón A. DN A strand breaks in human nasal respiratory epithelium are induced upon exposure to urban pollution. Environ Health Perspect 1996;104(2):160-167.

16. Rojas E, Valverde $M$, Sordo $M, 0$ strosky-W egman P. DN A damage in exfoliated buccal cells of smokers assessed by the single cell gel electrophoresis assay. Mutat Res 1996;370:115-120.

17. Cox DH.Arsine evolution-electrothermal atomic absorption method for the determination of nanogram levels of total arsenic in urine and water. J Anal Toxicol 1980;4:207-211.

18. Bousnes RW, Tawssky HH. O n the colorimetric determination of creatinine by the Jaffe reaction.J Biol Chem 1945;158:581.

19.Valverde M, Lopez MC, Lopez Y, Sanchez Y, Fortoul TI, 0 strosky-W egman $P$ et al. Environ Mol Mutagen 1997;30:147-152.

20. Andreoli $C$, Leopardi $P, C$ rebelli R. D etection of DN A damage in human lymphocytes by alkaline single cell gel electrophoresis after exposure to benzene or benzene metabolites. Mutat Res 1997:377:95-104.

21. Reese E, Kimbrough RD.A cute toxicity of gasoline and some additives. Environ Health Perspect 1994;101:115-131.

22. 0 strosky-W egman P, Gonsebatt ME, Montero R, Vega L, Barba H, Espinosa J et al. Lymphocyte proliferation kinetics and genotoxic findings in a pilot study on individuals chronically exposed to arsenic in Mexico. Mutat Res 1991; 250:477-482.

23. Gonsebatt ME,Vega L, Salazar AM, Montero R, Guzman P, Blas J et al. Cytogenetic effects in human exposure to arsenic. Mutat Res 1997;386: 219-228.

24. Ramirez P, Eastmond DA, Laclette JP , 0 strosky-W egman P. D isruption of microtubule assembly and spindle formation as a mechanism for the induction of aneuploid cell by sodium arsenite and vanadium pentoxide. Mutat Res 1997:386:291-298.

25. Salazar AM, O strosky-W egman P, Menendez D, Miranda E, G arcia-CarrancaA, Rojas E. Induction of p53 protein expression by sodium arsenite. Mutat Res 1997;381:259-265.

26. Carson RL. La primavera silenciosa. México D.F.: Editorial Grijalbo. 1980:334. 